\title{
Thinking after Drinking: Impaired Hippocampal-Dependent Cognition in Human Alcoholics and Animal Models of Alcohol Dependence
}

\author{
Miranda C. Staples ${ }^{\dagger}$ and Chitra D. Mandyam *t \\ Committee on the Neurobiology of Addictive Disorders, The Scripps Research Institute, La Jolla, CA, USA
}

OPEN ACCESS

Edited by:

Vincent David,

Centre National de la Recherche

Scientifique (CNRS), France

Reviewed by:

Gabriel Rubio,

Hospital Universitario

12 De Octubre, Spain

Myeong OK Kim,

Gyeonsang National

University Jinju, South Korea

${ }^{*}$ Correspondence:

Chitra D. Mandyam

cmandyam@scripps.edu

${ }^{t}$ Present address:

Miranda C. Staples

MileStone Research Organization,

San Diego, CA, USA;

Chitra D. Mandyam,

Veterans Administration

San Diego Healthcare System,

San Diego, CA, USA

Specialty section:

This article was submitted to Addictive Disorders, a section of the journal

Frontiers in Psychiatry

Received: 15 July 2016 Accepted: 13 September 2016 Published: 30 September 2016

Citation:

Staples MC and Mandyam CD (2016) Thinking after Drinking: Impaired Hippocampal-Dependent Cognition in Human Alcoholics and Animal Models of Alcohol Dependence.

Front. Psychiatry 7:162.

doi: 10.3389/fpsyt.2016.00162
Alcohol use disorder currently affects approximately 18 million Americans, with at least half of these individuals having significant cognitive impairments subsequent to their chronic alcohol use. This is most widely apparent as frontal cortex-dependent cognitive dysfunction, where executive function and decision-making are severely compromised, as well as hippocampus-dependent cognitive dysfunction, where contextual and temporal reasoning are negatively impacted. This review discusses the relevant clinical literature to support the theory that cognitive recovery in tasks dependent on the prefrontal cortex and hippocampus is temporally different across extended periods of abstinence from alcohol. Additional studies from preclinical models are discussed to support clinical findings. Finally, the unique cellular composition of the hippocampus and cognitive impairment dependent on the hippocampus is highlighted in the context of alcohol dependence.

Keywords: alcohol use disorder, cognitive impairment, abstinence, hippocampus, prefrontal cortex

\section{OCCURRENCE AND IMPACT OF ALCOHOL USE DISORDERS IN THE UNITED STATES}

In the United States, 18 million individuals (7.4\% of the 15 and older population, according to estimates from 2010) report having an alcohol use disorder (AUD), with nearly 12 million of these individuals reporting alcohol dependence (1). Recent changes to the diagnostic definition of AUDs in the updated DSM-V eliminate the clinical distinction between AUDs and alcohol dependence, opting to categorize them together under the umbrella category of AUDs and describe the broad disorder as a "... problematic pattern of alcohol use leading to clinically significant impairment or distress ..." as well as requiring concurrent escalation of alcohol intake, craving for alcohol, and significant disruptions to personal and professional conduct (2). In 2011, AUDs cost the United States $\$ 223.5$ billion, an estimation which includes the cost of medical treatment, judiciary involvement, and loss of productivity (3).

However, these statistics, while useful in conveying the gravity of the alcohol abuse problem in the United States, do not provide insight into the recovery process nor the continuing health

Abbreviations: AUD, alcohol use disorder; BALs, blood alcohol levels; BOLD, blood-oxygen-level dependent; CIE, chronic intermittent ethanol vapor exposure; DG, dentate gyrus; fMRI, functional magnetic resonance imaging; GABAa, gammaaminobutyric acid A subunit; GABAaR, GABAa Receptor; GluN, $N$-methyl-D-aspartate glutamatergic receptor; PFC, prefrontal cortex; TFC, trace fear conditioning. 
and cognitive disparities these individuals face into periods of abstinence from alcohol consumption. Additionally, long-term alcohol abuse results in significant, non-economic personal costs, including devastating bodily harm, with some of the most striking effects apparent in the brain. Evidence from human and animal studies suggest that select regions of the cortex, particularly the prefrontal cortex (PFC) and hippocampus, may be more sensitive to the deleterious and damaging effects of long-term alcohol use than others, and recovery of cognitive function sensitive to these regions may occur at different times into periods of prolonged abstinence (4-7).

\section{IMPACT OF ALCOHOL ON COGNITION: CLINICAL FINDINGS}

Alcohol is widely known to acutely alter cortical function by modulating inhibitory and excitatory receptor function on neuronal processes $(8-10)$. By repressing excitatory transmission $(8,11-15)$ and concurrently enhancing inhibitory transmission (16-21), alcohol acutely acts as a systemic depressant. Over repeated, chronic exposures, neuronal transmission achieves a homeostatic state in the presence of alcohol (22), and cognition can resemble that of non-dependent function. However, during periods of abstinence when alcohol is absent from the system for extended phases, effectively disrupting the previously described modified homeostasis, cognitive function is significantly impaired (due to the absence of alcohol as critical modulating factor), and these cognitive impairments persist for some time. Interestingly, these cognitive perturbations, in some instances, do recover to or near pre-dependency levels. What follows is a description and synthesis of how alcohol modulates PFC and hippocampal function, what changes occur as occasional alcohol consumption becomes chronic consumption, and what cognitive impairments are present during acute withdrawal.

It is worth noting, while outside the general scope of this review, that chronic alcohol use does result in structural and/or functional atrophy in regions outside of the PFC and hippocampus and that these additional changes cannot be eliminated as potential modulators of the deleterious effects observed in the PFC and hippocampus (23). Further, research into the cognitive capacities of alcoholic individuals has identified cognitive disorders, such as Wernicke-Korsakoff syndrome, alcohol dementia, and Marchiafava-Bignami disease, which are directly related to long-term alcohol abuse and cloud our understanding of alcohol's solitary effects on cognitive functioning $(24,25)$. Similarly, age and concurrent drug use can additionally complicate our understanding of alcohol's impact; therefore, for the purpose of this review, studies including subjects with chronic alcohol use without poly drug use were evaluated.

\section{COGNITIVE IMPAIRMENT FOLLOWING NONDEPENDENT ALCOHOL USE}

\section{Prefrontal Cortex}

The PFC is a region of the cerebrum, which has been colloquially referenced as the switchboard of the cortex due to its role in planning and selecting appropriate responses and actions to events and stimuli (26-28). Behaviors such as impulsivity (29), decision-making (30), and attentional focus (31) are all under the control of the PFC and are often manipulated and impaired in individuals with an AUD (discussed subsequently). Whenassessed in a controlled setting, acute doses of alcohol $(0.4-0.8 \mathrm{~g} / \mathrm{kg})$ given to nondependent subjects impairs numerous PFC functions, including disruption in planning (32), increases in impulsive actions (33-36), decreases behavioral inhibition (37-39), reduces perseverance (40), and increases poor decision-making (41). In many studies, these dysfunctions were correlated with reductions in typical lateralization (asymmetric distribution of activity) (36) as well as reduced functional magnetic resonance imaging (fMRI) activity during false responses (42). Further, studies in humans have demonstrated subtle structural abnormalities (43), increased blood flow (as an indicator of cortical activity) (44-47), and reduced hemispheric dominance $(36,48-50)$. Taken together, it is clear that the function of the PFC is significantly impaired with acute exposures to alcohol.

\section{Hippocampus}

Similar to the inhibition observed in the PFC, the hippocampus is a sensitive target of alcohol's actions in the brain. Defined, in part, by its characteristic trisynaptic circuit, human and animal studies have demonstrated that the hippocampus is critical for spatial memory [reviewed in Ref. (51)], context discrimination (52), pattern separation (53), and time-sensitive memories (54). A critically unique region of the hippocampus, the dentate gyrus (DG), contains neural stem cells that continue to divide and primarily generate functional neurons into adulthood in nearly all mammalian species (55) and have proved critical for pattern separation functionality (56). Beyond its role in the previously described functions, the hippocampus plays a critical role in emotional and stress regulation (57), critical components to the development and cyclical nature of addiction (58). In human subjects, hippocampal function is typically assessed as contextual memory or episodic memory, both of which have been shown to be impacted during acute alcohol exposure $(49,59)$.

\section{COGNITIVE IMPAIRMENTS DURING AND FOLLOWING HEAVY ALCOHOL USE}

\section{Prefrontal Cortex}

When compared with healthy subjects, individuals reporting chronic alcohol abuse demonstrate structural abnormalities, including reduced frontal cortical volume (60-64), compromised white matter integrity (65-67), reduced quantities of frontal-cerebellar connections (68), and aberrant patterns of frontal cortical activity $(69,70)$. Further, Kril et al. (71) confirmed previously reported reductions in PFC white matter and found a significant reduction in the number of neurons in postmortem tissue of alcoholics when compared with healthy control subjects, confirming losses to cortical gray matter (60). Finally, it is possible that these pathological changes are underlying the diminished cognitive function often observed in human alcoholics. 
In order to test the deleterious effects of chronic alcohol abuse on the intellectual capacities of alcohol-dependent individuals, tests of memory, impulsivity, risk, and attention are often employed. While individuals struggling with alcohol dependence rarely exhibit impairments on assessments of generalized intelligence, specialized complex tasks are uniquely able to elucidate potentially subtle difference between dependent and non-dependent populations. Estimates suggest that at least half of individuals diagnosed as alcohol-dependent are also cognitively challenged (4). One early study assessing a group of recently abstinent alcoholics, individuals with frontal lobe damage, and healthy controls found, as expected, no difference on assessments of IQ, but did report that alcoholic individuals were significantly impaired compared with both controls and individuals suffering from frontal lobe trauma in tasks that were designed to explicitly test frontal lobe function $(72,73)$. More recent studies have demonstrated explicit impairments on tasks, involving executive functioning $(74,75)$, working memory $(76,77)$, and impulsivity (76, 78-81). Structural abnormalities have been directly linked to frontal cortical function in within-subject experimental designs. One study measuring frontal cortical electrical activity (electroencephalogram recordings) during a Go/No Go task, a test where subjects are asked to learn and perseverate changing rules pertaining to cues, demonstrated blunted activity during the task in alcoholics as compared with non-dependent controls (82). Most recently, Nakamura-Palacios et al. (83) reported that the damage to the PFC was predictive of the cognitive impairments on tests of executive function. Additionally, studies have identified abnormal patterns of activity during cognitive tasks in alcohol-dependent subjects, whose intellectual performance is comparable to non-dependent subjects (84); this finding is particularly intriguing as it implies that individuals with significant disruptions in cognitive capacities may lack the capacity to form adaptive connections in the presence of chronic alcohol. Taken together, these findings present solid evidence that the PFC is subject to extensive damage as a result of chronic alcohol use, some of which could potentially be mediated by certain individual characteristics.

\section{Hippocampus}

Studies involving human subjects with chronic alcohol use have demonstrated reduced hippocampal volume (85-87), postmortem evidence of prior neuronal loss (88), and severely reduced hippocampal activity, including reductions in blood flow (89). Recently, one study comparing mild and heavy drinkers demonstrated no significant impairment of general cognition but an increased fMRI blood-oxygen-level-dependent (BOLD) response, an indicator of regional activity, in the hippocampus during correct responses to the visual encoding and memory task, implying a compensatory mechanism for cognitive function (90). However, tasks capable of identifying explicit hippocampal-sensitive cognitive impairments in adults, particularly those with substance dependency issues, are scarce beyond those investigating episodic memory. Episodic memory, or the function of remembering events in specific spatial and temporal context (in contrast to factual or semantic memory), is an important hippocampal function in humans $(91,92)$ and has been demonstrated to be significantly impaired in alcoholic patients (93-96). However, it should be noted that as described by Noel et al. (96), episodic memory is also sensitive to alcoholinduced damage to the PFC, so the findings of reduced episodic memory function cannot be explicitly attributed to impaired hippocampal function.

\section{RECOVERY OF COGNITIVE CAPACITIES}

A strong body of evidence in alcohol-dependent individuals has demonstrated that various cognitive capacities do return to (or nearly to) non-dependence levels of performance. However, the details of this recovery vary widely in terms of temporal resolution based primarily on the cortical structure of interest, and it is difficult to disseminate apparent recovery of damaged regions from compensation by other cortical regions with regards to behavioral function and performance alone. For example, studies appear to suggest that cognitive deficits due to PFC damage from alcohol abuse recover on a shorter timescale compared with those dependent on the hippocampus. However, as the functionality of the PFC and hippocampus is intricately related, there is a clear challenge to designing studies to directly address the explicit temporal recovery of specific structures in humans. Therefore, the findings presented here are from studies addressing broader questions of functionality in alcoholics.

With respect to the PFC damage, recovery of cognitive function in this region is critical to the persistence of abstinence from alcoholism and avoidance of relapse in dependent individuals (97). A recent met-analysis of human literature (62 sources in all) demonstrated that cognitive impairments sensitive to the PFC in individuals with AUDs identified in recent abstainers (98-101) are primarily alleviated or "normalized" (meaning performance is comparable to non-dependent individuals) by 1-year abstinence of alcohol use (102). Similarly, improvements in executive functioning occurring as soon as 6 months into abstinence has been reported $(95,103)$. However, as proposed and reviewed by Oscar-Berman et al. (104), it is plausible that the recovery of PFC function is more the result of compensatory activity in associated regions of the cortex rather than distinct recovery or repair of the PFC itself.

With regard to hippocampal functionality, human studies evaluating episodic memory in dependent, long-term abstinent individuals have reported similar findings to those relating to the PFC, but the outcomes of the studies have not been entirely equivocal. For example, multiple studies have reported impaired performance on tasks of episodic memory (105-107), and that "normalization" of episodic memory performance in alcoholdependent subjects has taken place by 1 year of abstinence (95). However, there is evidence that hippocampal dysfunction remains impaired years after abstinence $(5,108)$. The potential distinction of these two seemingly disparate findings may be the result of (A) many of the studies not evaluating function beyond 1-year abstinence and (B), as described previously, episodic memory is not entirely exclusive of hippocampal function. Therefore, it is possible that, while episodic memory function returns, other facets of hippocampal function remain perturbed long into 
abstinence from alcohol. Taken together, the current evidence suggests that the recovery of cognitive functionality in abstinent alcohol-dependent individuals is sensitive to the duration of the abstinence period, with the PFC returning to "normative" levels prior to the hippocampal formation.

\section{LIMITATIONS OF CLINICAL FINDINGS}

A wealth of evidence from clinical findings demonstrates that acute alcohol exposures can inhibit cognitive capacities. Interestingly, it is primarily following withdrawal from chronic alcohol exposure that individuals experience persisting, severe cognitive impairments. As eloquently described in Oscar-Berman et al. (104), studies involving human subjects and drugs of abuse are often rife with complicating and confounding factors, including family history, genetic predisposition, and past life events and experience, much of which cannot be controlled for. While clinical studies are limited to observational investigations into the deleterious cortical adaptations subsequent to chronic alcohol exposure, preclinical models have been successful at informing and elaborating our understanding of the cellular and molecular changes, which may explain the mechanisms underlying cognitive disparities in abstinent alcohol-dependent subjects. Further, preclinical models of alcohol dependence have generated evidence suggesting that the distinct cellular compositions of the PFC and the hippocampus may be the basis for the differential cognitive recovery in these regions in abstinent individuals. Therefore, the following sections will discuss preclinical models of alcohol addiction and dependence with specific focus on cognitive impairments dependent on the PFC and hippocampus and will elucidate the associated cellular and molecular changes in these regions.

\section{IMPACT OF ALCOHOL ON COGNITION: PRECLINICAL FINDINGS}

Rodent models of alcohol dependence have been instrumental in furthering our understanding of both the cognitive and neurobiological impact of withdrawal from alcohol dependence, as well as providing critical insight into the potential mechanisms of the pathological state associated with and resulting from alcohol withdrawal in dependent animals. While studies targeting examination of one explicit region or feature are impossible in human populations, particularly with regards to the effects of drugs of abuse, animal models have been instrumental tools in allowing for the fine manipulation of explicit cortical regions and functions.

\section{ALCOHOL IMPAIRS PFC FUNCTION}

Multiple studies employing rodent models have investigated the impact of alcohol dependence on prefrontal cognitive capacity. Growing evidence suggests that the rodent medial prefrontal cortex (mPFC) likely represents a functional homolog of the human medial and dorsolateral PFC (109). Reports using various rodent models of alcohol dependence [including chronic intermittent ethanol vapor exposure (CIE), liquid diet, two bottle choice; for paradigm overviews, see Ref. (110)] have found behavioral inflexibility (111), impaired extinction (112), impaired setshifting (113), and impaired working memory $(114,115)$, all tasks which require a fully functioning PFC. Further, two of these studies $(112,113)$ linked the disruption in frontal cortical function to alcohol-induced dysregulation of the $N$-methyl-D-aspartate glutamatergic receptor (GluN) system. Two studies have investigated PFC functions into periods of abstinence following chronic ethanol exposure via CIE (10 days abstinence; (116)), or liquid diet (6 weeks abstinence; (114)). Interestingly, at 10 days into abstinence there is a lack of impairment in cognitive flexibility while at 6 weeks into abstinence there were severe impairments in working memory. Furthermore, investigation of anxietylike behavior, 6 weeks into abstinence, demonstrated a lack of emotional behavioral deficit in abstinent animals (114). Taken together, it is evident that the paradigm of ethanol experience and the type of behavioral investigation are critical when determining alterations in PFC-dependent functions during abstinence, and that some PFC-dependent behaviors are less sensitive to the neurobiological alterations in the PFC in abstinent animals compared with others.

\section{ALCOHOL IMPAIRS HIPPOCAMPAL FUNCTION}

Animal models have also been critical in resolving the explicit impact of chronic alcohol on the functionality of the hippocampus. Similar to the studies in animal models of alcohol dependence, which replicated the PFC impairments observed in humans, studies in animals exposed to translationally relevant models of chronic alcohol exposure have reproduced and expanded on the findings from human subjects. These studies have resulted in numerous structural and functional abnormalities of the rodent hippocampus similar to those seen in human studies. For example, studies in rodents employing forced chronic consumption demonstrate long-term exposures to alcohol resulted in extensive impairment in spatial memory (117-122). Unfortunately, behavioral disparities in these preclinical models have been limited to the spatial and contextual processing functions of the hippocampus with no reference to the temporal discrimination role of this structure. Nevertheless, it is clear that chronic alcohol exposure critically impairs hippocampal function in preclinical models similar to those previously discussed in clinical settings, although there remain unanswered questions in this field with regard to the complete profile of hippocampal cognitive impairments. The remainder of the review will focus on the hippocampus and provide a brief overview of the cellular and molecular mechanisms in the hippocampus that could contribute to the long-term impairments in the behaviors dependent on the hippocampus in preclinical models of AUDs.

\section{MOLECULAR ACTIONS OF ALCOHOL IN THE HIPPOCAMPUS}

\section{Acute Effects on GluNs}

Animal models of acute alcohol exposure have been instrumental in elucidating our understanding of the molecular actions of 
alcohol with regard to excitatory and inhibitory transmission in the mammalian cortex (see Figure 1A for a summary). GluNs are one of the main components of excitatory transmission in the hippocampus (as well as the cortex at large) and are critical for learning and memory (123). The receptors are comprised of four subunits, two obligatory GluN1 subunits, and two additional subunits, which can be any of GluN2A-D or GluN3A-B. Evidence suggests that the $2 \mathrm{~A}$ and $2 \mathrm{~B}$ subunits, expressed in high density in the hippocampus, are particularly sensitive to alcohol's inhibitory effects (124-127). Further, early evidence suggests that alcohol dose-dependently inhibits GluN-dependent current in cells (8) by decreasing the time the channel spends open (128).

\section{Acute Effects on Gamma-Aminobutyric Acid A Receptors}

Inhibitory transmission plays a similarly critical role in cognition, learning, and memory in the hippocampus (and the cortex at large) (129). In addition to alcohol's reduction of glutamatergic transmission via impairment of GluN function, alcohol also acts as a non-competitive agonist, directly enhancing the chloride transmission of the gamma-aminobutyric acid A (GABAa) channel (130) effectively hyperpolarizing the neural cells (see Figure 1A for a summary). Similar to GluN, the GABAa receptor (GABAaR) is comprised of five subunits, typically two alpha (A1-6), two beta (B1-3), and one subunit, which could be comprised of a gamma (G1-3) or delta. However, unlike GluN, the precise site of action on a given subunit is of debate [reviewed in Ref. (21)], with many subunits demonstrating sensitivity to alcohol (131), and much evidence is contradictory; for example, Wallner et al. (20) suggested that the B3 subunit was mediating the receptor's sensitivity to alcohol, but this was later contradicted in a mutant mouse model void of the B3 subunit, but still demonstrated GABA-ergic enhancement following alcohol administration (132). It is highly possible that alcohol's capacity to enhance inhibitory function of the GABAaR is dependent on the specific conformation of subunits instead of acting at a single subunit.

\section{Chronic Effects on GluNs}

$\mathrm{N}$-methyl-D-aspartate glutamatergic receptors and associated intracellular signaling molecules adapt to the reoccurring
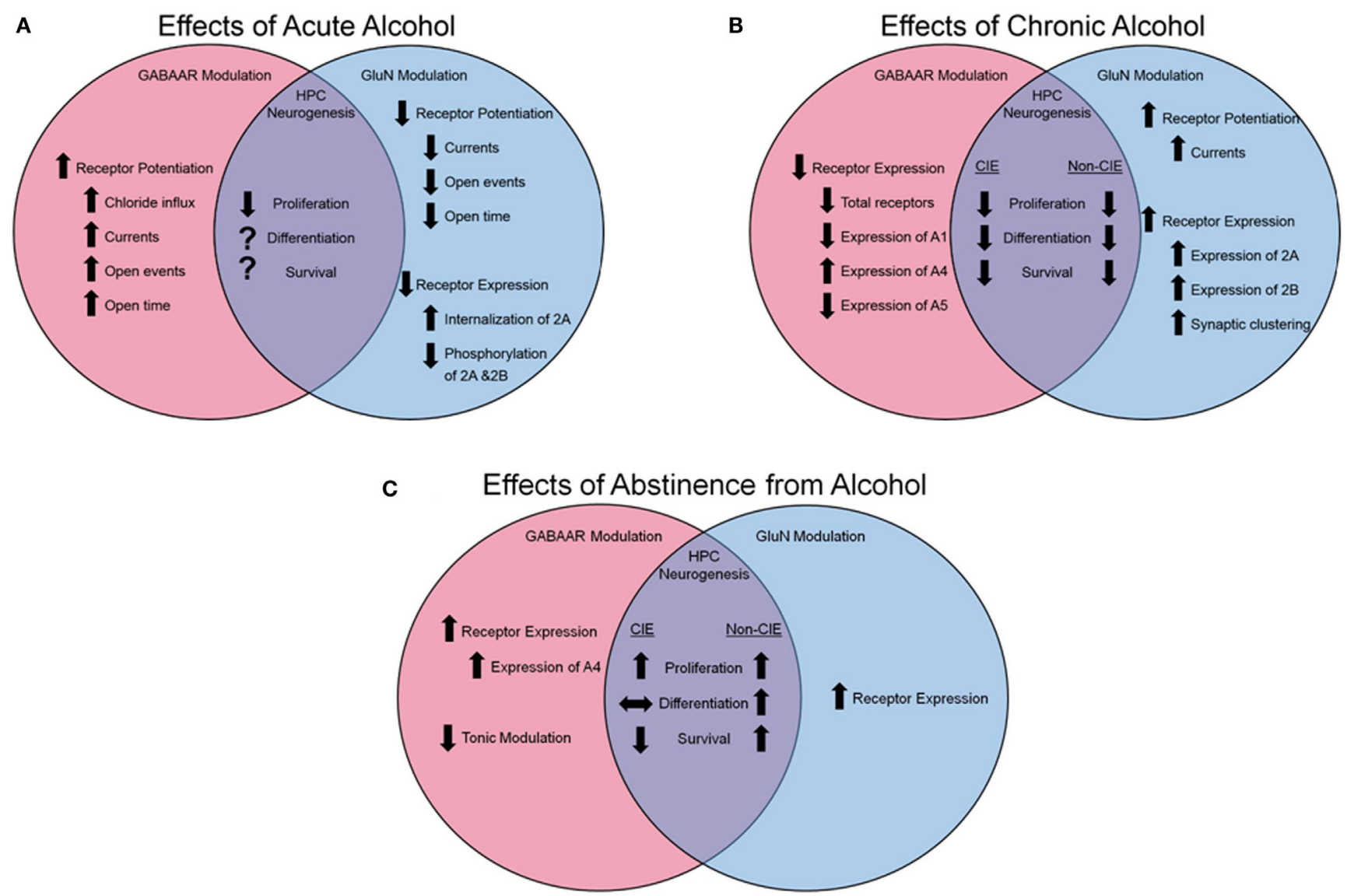

FIGURE 1 | Effects of alcohol on GABAa and GluN receptor modulation and hippocampal neurogenesis. (A) Influence of acute alcohol exposure on receptor function and expression and HPC neurogenesis. (B) Influence of chronic alcohol exposure on receptor function and expression and HPC neurogenesis. (C) Influence of abstinence from alcohol on receptor function and expression and HPC neurogenesis. Arrows pointing up indicate an increase, arrows pointing down indicate a reduction, arrows pointing side to side indicate no change, and a question mark indicates that information is not available. 
presence of alcohol, facilitating the development of the dependent phenotype. Post-translationally, the GluN2B subunit is phosphorylated subsequent to alcohol exposure (133), particularly in the hippocampus (13), resulting in an increase in receptor function. Over repeated alcohol exposures, an increase in expression of GluN subunits 2A and 2B $(134,135)$, synaptic-specific clustering of GluNs (136), as well as an increase in GluN-mediated currents (136) are observed (Figure 1B). It is probable that this increase in expression and function of the GluN receptor is a compensatory mechanism against chronic alcohol's impairment on the receptor; however, when alcohol is absent from the cortical system during withdrawal, the pathologic over-expression of GluNs (137), along with the normalized GABA-ergic function in the absence of alcohol's facilitating effects, results in cortical hyperactivity and excitotoxicity.

\section{Chronic Effects on GABAaRs}

In addition to the molecular changes observed in the GluN system following long-term alcohol exposures, the GABAaRs are subject to dynamic regulation by the drug (see Figure $\mathbf{1 B}$ for a summary). The subunits of the GABAaR are differentially expressed subsequent to chronic alcohol in a region- and subunit-specific manner [for detailed review see Ref. (138)]. Evidence suggests an exchange of subunits expressed on the cell surface with a reported reduction in A1 subunits in the hippocampus (139) and an increase of A4 (140-142) and A5 (139) following CIE. However, subunit expression is not the only element of GABAaR modulation that is altered by chronic alcohol exposure. Following withdrawal from CIE, neurons displayed heightened excitability, which was pharmacologically attributable to increases in the number of A4 containing GABAaRs (142) as well as reductions in tonic current modulators (143), increase in A4 synaptic localization (144), and subunit-specific changes in trafficking (145), leading to a preferential increase in A4 expression over other subunits. Therefore, following chronic alcohol exposure, there is a generalized reduction of GABAaR functionality, leading to heightened neuronal activity in the absence of alcohol's modulating effects.

\section{POTENTIAL BIOLOGICAL MECHANISM OF HIPPOCAMPAL SENSITIVITY TO AUDS: IMPACT OF ALTERED GIUN AND GABAR SIGNALING IN THE HIPPOCAMPUS ON ADULT NEUROGENESIS}

The regionally differential rates of cognitive recovery following abstinence from alcohol use are potentially consequent to the neurogenic properties (or lack thereof) of each region. To be more specific, cognitive function relying on the frontal cortical region in humans has been described as being recovered at an earlier time in abstinence than cognitive functions specific to the hippocampal formation of the limbic system as previously discussed. It is possible that this disparity is due to, at least in part, the ongoing adult neurogenesis in the hippocampus which occurs at a much lesser rate in the PFC of mammals (146); neurons which would be generated during critical periods of withdrawal would be developing into mature neurons during a time of negative affect $(147,148)$, potentially resulting in a pathologic phenotype and dysfunctional characteristics (149). This problematic phenomenon would be far more impactful in a region with high neurogenesis (such as the hippocampus) as compared with a region of low or absent neurogenesis, where the typical functioning of the existing circuitry may return upon complete washout of the drug.

Adult mammalian neurogenesis is a widely accepted phenomenon, as evidence demonstrates the existence of mitotically active cells in distinct regions of the brain, one which is the granule cell layer of the DG of the hippocampus. Neurogenesis, or the process of proliferation, differentiation, and maturation of neural progenitor cells to fully functional and integrated neuronal components of the surrounding network $(150,151)$, has been confirmed in numerous mammalian species, including humans (152). Assessment of cell number and structure at various time points following cell birth can provide insight into the impact of exogenous factors on the neurogenic process in the hippocampus [for comprehensive review of granule cell development see Ref. (153)].

The explicit functionality of these adult-born cells is still a topic of contention. Hippocampal-sensitive learning has been shown to positively influence proliferation and survival of new neurons [reviewed in Ref. (154)]; inversely, increases in proliferation or survival of newly born neurons can increase performance on hippocampal-sensitive tasks, while reductions or ablations of neuronal proliferation results in problematic cognitive performance [reviewed in Ref. (155)]. Acquisition, retention, and extinction of trace fear conditioning (TFC; a hippocampus sensitive task) has been shown to be sensitive to changes in neurogenesis (156) due to or as a result of its hippocampal-dependence (157), but as yet, investigations into the impact of clinically relevant models of chronic alcohol on TFC performance have not been reported.

\section{Regulation of Neurogenesis by GluNs}

Glutamatergic signaling via GluNs is of critical importance in regulating neural stem cells in the hippocampus, particularly in the withdrawal/abstinence period in alcohol-dependent subjects. Under basal conditions, some stages of immature neural progenitors (proliferating and differentiating cells) in the hippocampus express GluNs (158). When coupled with the evidence that GluNdependent long-term potentiation in the DG can increase progenitor proliferation $(159,160)$ and survival $(159)$, these findings imply that regulation of hippocampal neurogenesis is sensitive to GluN stimulation on newly born granule cells. Alcohol's longterm actions via GluNs would, therefore, affect proliferation, survival, and function of the newly born neurons in a dynamic manner which would change over the course of abstinence from alcohol. Alcohol, as described previously, has the consequence of maintaining GluNs at the synapse, effectively impairing cycling of receptors back into the cell for degradation or reuse. Therefore, the role of alcohol on hippocampal neurogenesis would be mediated by either GluN dysregulation, GABA-ergic dysregulation, or a balance of both.

\section{Regulation of Neurogenesis by GABAaRs}

The granule cells of the hippocampus are maintained in a quiescent state by the mossy fibers of the hilus via GABA-ergic 
regulation [reviewed in Ref. (161)]. Evidence has demonstrated that these cells do express GABAaRs (162), as do the surrounding cells of the DG $(163,164)$; therefore, not only are the granule cells sensitive to enhanced GABA-ergic transmission during exposure to chronic alcohol but are also subject to secondary regulation due to the modulation of activity of surrounding cells by alcohol's actions on the GABAaR. As specific subunit compositions of the GABAaR can modulate important stages of neurogenesis (particularly the maintenance of quiescent cells and proliferation), this could provide a potential mechanism by which alcohol could be modulating neurogenesis in dependent individuals. During periods of alcohol intake, GABAaR function would be supported and facilitated such that quiescent cells would be maintained $(165,166)$ as such and proliferation would be reduced (167-169). In the acute absence of alcohol, the facilitation of GABAaR activity would be lost and quiescent cells would be allowed to proliferate, and these effects could result in increase or decrease in cell survival in the days following withdrawal (169-171). However, impaired GABA-ergic receptor function has been shown to restrict morphology of newly born cells (172), which could reduce the number of synaptic connections and network integration required for survival and function of the granule cells and, therefore, result in net reduction of the number of surviving cells during protracted abstinence (171). This finding serves as a potential argument for the reduced survival subsequent to the increased proliferation following withdrawal in dependent animals (171).

\section{Regulation of Neurogenesis by Alcohol}

In addition to a general understanding of neurogenesis, we are beginning to understand how alcohol exposure impacts hippocampal neurogenesis and what this may imply for cognitive performance and capacity (see Figures 1A-C for a summary). For example, while cellular proliferation and neurogenesis are reduced during excessive alcohol-induced dependence (167-169), early withdrawal from excessive alcohol is documented to result in an increase in cellular proliferation in the DG (169-171). The survival capacity of progenitors born during this period of increased proliferation and their functional importance is still unclear; however, reports using alcohol gavage [blood alcohol levels (BALs) reaching > $400 \mathrm{mg} \%$ ] demonstrate increased survival of newly born neurons subsequent to the proliferative burst $(170,173,174)$. In contrast, animals made dependent to alcohol via ethanol vapor exposure (BALs maintained between 150-250 mg\%) demonstrate a marked reduction in the number of surviving young neurons in the DG $(169,171)$. This difference could be attributed to differences in BALs and negative affect symptoms resulting from the exposure paradigm (gavage vs. CIE). Unfortunately, there is no conclusive evidence linking aberrant neurogenesis subsequent to alcohol dependence and impaired hippocampal cognitive function. Future studies will be required to demonstrate the plausibility of this mechanism as an underlying explanation for the deleterious effect of alcohol dependence on hippocampal function.

\section{SUMMARY AND CONCLUSION}

The goal of this review was to provide initial evidence in support of the proposal that the cognitive recovery of the hippocampus and the PFC following abstinence from long-term alcohol abuse occur at different rates, potentially due to their difference in cellular composition and neurogenic functionality. For example, clinical evidence supports recovery of certain PFC-dependent tasks in times of abstinence from alcohol at different rates compared with hippocampal-dependent tasks. Preclinical findings in animal models of alcohol exposure support the clinical observation; mechanistic studies support that this temporally differential rescue of PFC-dependent tasks is potentially due to the neurogenic deficits in the hippocampus during abstinence, such that the birth of new neurons during periods of negative affect result in the persistence of the hippocampal-specific cognitive disparities.

\section{FUTURE PERSPECTIVE}

Many questions remain unanswered with regard to human hippocampal function during periods of alcohol abstinence. For example, it is clear that employing cognitive therapy can support individuals in successful attempts at abstinence. Given that extinction training is being adopted in clinical behavioral therapy to promote recovery from relapse (175), it is critical to investigate similar potential therapeutic strategies (be it behavioral or pharmacological), which will serve this purpose not only to ameliorate the cognitive disparities in these individuals but to facilitate dependent individuals in avoiding relapse to alcohol abuse.

\section{AUTHOR CONTRIBUTIONS}

MS was responsible for the article concept and drafted the manuscript. CM and MS provided critical revision of the manuscript for important intellectual content. Both authors critically reviewed content and approved final version for publication.

\section{FUNDING}

The authors would like to acknowledge McKenzie Fannon-Pavlich for her critical reviewing of this manuscript. Funding for this manuscript provided by the National Institute of Alcoholism and Alcohol Abuse grants to MS (T32AA00747 and F32AA023690) and CM (AA020098 and AA06420). This is manuscript number 28063 from The Scripps Research Institute. 


\section{REFERENCES}

1. World Health Organization. Global Status Report on Alcohol and Health 2014. Geneva: WHO (2014).

2. American Psychiatric Association, A.P.A.D.S.M.T.F. Diagnostic and Statistical Manual of Mental Disorders: DSM-5. USA: American Psychiatric Association (2013).

3. Bouchery EE, Harwood HJ, Sacks JJ, Simon CJ, Brewer RD. Economic costs of excessive alcohol consumption in the U.S., 2006. Am J Prev Med (2011) 41:516-24. doi:10.1016/j.amepre.2011.06.045

4. Fein G, Bachman L, Fisher S, Davenport L. Cognitive impairments in abstinent alcoholics. West J Med (1990) 152:531-7.

5. Fein G, Torres J, Price LJ, Di Sclafani V. Cognitive performance in long-term abstinent alcoholic individuals. Alcohol Clin Exp Res (2006) 30:1538-44. doi:10.1111/j.1530-0277.2006.00185.x

6. Fein G, Shimotsu R, Chu R, Barakos J. Parietal gray matter volume loss is related to spatial processing deficits in long-term abstinent alcoholic men. Alcohol Clin Exp Res (2009) 33:1806-14. doi:10.1111/j.1530-0277.2009. 01019.x

7. Bernardin F, Maheut-Bosser A, Paille F. Cognitive impairments in alcohol-dependent subjects. Front Psychiatry (2014) 5:78. doi:10.3389/ fpsyt.2014.00078

8. Lovinger DM, White G, Weight FF. Ethanol inhibits NMDA-activated ion current in hippocampal neurons. Science (1989) 243:1721-4. doi:10.1126/ science. 2467382

9. Mihic SJ, Harris RA. Inhibition of rhol receptor GABAergic currents by alcohols and volatile anesthetics. J Pharmacol Exp Ther (1996) 277:411-6.

10. Valenzuela CF. Alcohol and neurotransmitter interactions. Alcohol Health Res World (1997) 21:144-8.

11. Lovinger DM, White G, Weight FF. NMDA receptor-mediated synaptic excitation selectively inhibited by ethanol in hippocampal slice from adult rat. I Neurosci (1990) 10:1372-9.

12. Wirkner K, Eberts C, Poelchen W, Allgaier C, Illes P. Mechanism of inhibition by ethanol of NMDA and AMPA receptor channel functions in cultured rat cortical neurons. Naunyn Schmiedebergs Arch Pharmacol (2000) 362:568-76. doi:10.1007/s002100000262

13. Yaka R, Phamluong K, Ron D. Scaffolding of Fyn kinase to the NMDA receptor determines brain region sensitivity to ethanol. JNeurosci (2003) 23:3623-32.

14. Yaka R, Tang KC, Camarini R, Janak PH, Ron D. Fyn kinase and NR2Bcontaining NMDA receptors regulate acute ethanol sensitivity but not ethanol intake or conditioned reward. Alcohol Clin Exp Res (2003) 27:1736-42. doi:10.1097/01.ALC.0000095924.87729.D8

15. Hendricson AW, Sibbald JR, Morrisett RA. Ethanol alters the frequency, amplitude, and decay kinetics of Sr2+-supported, asynchronous NMDAR mEPSCs in rat hippocampal slices. J Neurophysiol (2004) 91:2568-77. doi:10.1152/jn.00997.2003

16. Allan AM, Harris RA. Gamma-aminobutyric acid and alcohol actions: neurochemical studies of long sleep and short sleep mice. Life Sci (1986) 39:2005-15. doi:10.1016/0024-3205(86)90324-3

17. Suzdak PD, Schwartz RD, Skolnick P, Paul SM. Ethanol stimulates gamma-aminobutyric acid receptor-mediated chloride transport in rat brain synaptoneurosomes. Proc Natl Acad Sci U S A (1986) 83:4071-5. doi:10.1073/ pnas.83.11.4071

18. Ticku MK, Lowrimore P, Lehoullier P. Ethanol enhances GABA-induced 36Cl-influx in primary spinal cord cultured neurons. Brain Res Bull (1986) 17:123-6. doi:10.1016/0361-9230(86)90168-1

19. Reynolds JN, Prasad A, MacDonald JF. Ethanol modulation of GABA receptor-activated Cl-currents in neurons of the chick, rat and mouse central nervous system. Eur JPharmacol (1992) 224:173-81. doi:10.1016/0014-2999(92)90802-B

20. Wallner M, Hanchar HJ, Olsen RW. Ethanol enhances alpha 4 beta 3 delta and alpha 6 beta 3 delta gamma-aminobutyric acid type A receptors at low concentrations known to affect humans. Proc Natl Acad Sci U S A (2003) 100:15218-23. doi:10.1073/pnas.2435171100

21. Lobo IA, Harris RA. GABA(A) receptors and alcohol. Pharmacol Biochem Behav (2008) 90:90-4. doi:10.1016/j.pbb.2008.03.006
22. Weiner JL, Valenzuela CF. Ethanol modulation of GABAergic transmission: the view from the slice. Pharmacol Ther (2006) 111:533-54. doi:10.1016/ j.pharmthera.2005.11.002

23. de la Monte SM, Kril JJ. Human alcohol-related neuropathology. Acta Neuropathol (2014) 127:71-90. doi:10.1007/s00401-013-1233-3

24. Costin BN, Miles MF. Molecular and neurologic responses to chronic alcohol use. Handb Clin Neurol (2014) 125:157-71. doi:10.1016/ B978-0-444-62619-6.00010-0

25. Vedder LC, Hall JM, Jabrouin KR, Savage LM. Interactions between chronic ethanol consumption and thiamine deficiency on neural plasticity, spatial memory, and cognitive flexibility. Alcohol Clin Exp Res (2015) 39:2143-53 doi:10.1111/acer.12859

26. Stuss DT, Gallup GG Jr, Alexander MP. The frontal lobes are necessary for 'theory of mind'. Brain (2001) 124:279-86. doi:10.1093/brain/124.2.279

27. Tanji J, Hoshi E. Role of the lateral prefrontal cortex in executive behavioral control. Physiol Rev (2008) 88:37-57. doi:10.1152/physrev.00014.2007

28. Kesner RP, Churchwell JC. An analysis of rat prefrontal cortex in mediating executive function. Neurobiol Learn Mem (2011) 96:417-31. doi:10.1016/ j.nlm.2011.07.002

29. Aron AR. The neural basis of inhibition in cognitive control. Neuroscientist (2007) 13:214-28. doi:10.1177/1073858407299288

30. Stuss DT. Functions of the frontal lobes: relation to executive functions. J Int Neuropsychol Soc (2011) 17:759-65. doi:10.1017/S1355617711000695

31. Rossi AF, Pessoa L, Desimone R, Ungerleider LG. The prefrontal cortex and the executive control of attention. Exp Brain Res (2009) 192:489-97. doi:10.1007/s00221-008-1642-z

32. Weissenborn R, Duka T. Acute alcohol effects on cognitive function in social drinkers: their relationship to drinking habits. Psychopharmacology (Berl) (2003) 165:306-12

33. Grillon C, Sinha R, O'Malley SS. Effects of ethanol on the processing of low probability stimuli: an ERP study. Psychopharmacology (Berl) (1995) 119:455-65. doi:10.1007/BF02245862

34. Reynolds B, Richards JB, de Wit H. Acute-alcohol effects on the Experiential Discounting Task (EDT) and a question-based measure of delay discounting. Pharmacol Biochem Behav (2006) 83:194-202. doi:10.1016/j.pbb.2006. 01.007

35. Dougherty DM, Marsh-Richard DM, Hatzis ES, Nouvion SO, Mathias CW. A test of alcohol dose effects on multiple behavioral measures of impulsivity. Drug Alcohol Depend (2008) 96:111-20. doi:10.1016/j.drugalcdep.2008. 02.002

36. Tsujii T, Sakatani K, Nakashima E, Igarashi T, Katayama Y. Characterization of the acute effects of alcohol on asymmetry of inferior frontal cortex activity during a Go/No-Go task using functional near-infrared spectroscopy. Psychopharmacology (Berl) (2011) 217:595-603. doi:10.1007/ s00213-011-2318-0

37. Mulvihill LE, Skilling TA, Vogel-Sprott M. Alcohol and the ability to inhibit behavior in men and women. J Stud Alcohol (1997) 58:600-5. doi:10.15288/ jsa.1997.58.600

38. de Wit H, Crean J, Richards JB. Effects of D-amphetamine and ethanol on a measure of behavioral inhibition in humans. Behav Neurosci (2000) 114:830-7. doi:10.1037/0735-7044.114.4.830

39. Fillmore MT. Drug abuse as a problem of impaired control: current approaches and findings. Behav Cogn Neurosci Rev (2003) 2:179-97. doi: $10.1177 / 1534582303257007$

40. Lyvers M, Tobias-Webb J. Effects of acute alcohol consumption on executive cognitive functioning in naturalistic settings. Addict Behav (2010) 35:1021-8 doi:10.1016/j.addbeh.2010.06.022

41. George S, Rogers RD, Duka T. The acute effect of alcohol on decision making in social drinkers. Psychopharmacology (Berl) (2005) 182:160-9. doi:10.1007/ s00213-005-0057-9

42. Anderson BM, Stevens MC, Meda SA, Jordan K, Calhoun VD, Pearlson GD. Functional imaging of cognitive control during acute alcohol intoxication. Alcohol Clin Exp Res (2011) 35:156-65. doi:10.1111/j.1530-0277.2010. 01332.x

43. Kong LM, Zheng WB, Lian GP, Zhang HD. Acute effects of alcohol on the human brain: diffusion tensor imaging study. AJNR Am J Neuroradiol (2012) 33:928-34. doi:10.3174/ajnr.A2873 
44. Volkow ND, Mullani N, Gould L, Adler SS, Guynn RW, Overall JE, et al. Effects of acute alcohol intoxication on cerebral blood flow measured with PET. Psychiatry Res (1988) 24:201-9. doi:10.1016/0165-1781(88) 90063-7

45. Sano M, Wendt PE, Wirsen A, Stenberg G, Risberg J, Ingvar DH. Acute effects of alcohol on regional cerebral blood flow in man. JStud Alcohol (1993) 54:369-76. doi:10.15288/jsa.1993.54.369

46. Tiihonen J, Kuikka J, Hakola P, Paanila J, Airaksinen J, Eronen M, et al. Acute ethanol-induced changes in cerebral blood flow. Am J Psychiatry (1994) 151:1505-8. doi:10.1176/ajp.151.10.1505

47. Rickenbacher E, Greve DN, Azma S, Pfeuffer J, Marinkovic K. Effects of alcohol intoxication and gender on cerebral perfusion: an arterial spin labeling study. Alcohol (2011) 45:725-37. doi:10.1016/j.alcohol.2011.04.002

48. Wendt PE, Risberg J. Ethanol reduces rCFB activation of left dorsolateral prefrontal cortex during a verbal fluency task. Brain Lang (2001) 77:197-215. doi:10.1006/brln.2000.2434

49. Soderlund H, Grady CL, Easdon C, Tulving E. Acute effects of alcohol on neural correlates of episodic memory encoding. Neuroimage (2007) 35:928-39. doi:10.1016/j.neuroimage.2006.12.024

50. Volkow ND, Ma Y, Zhu W, Fowler JS, Li J, Rao M, et al. Moderate doses of alcohol disrupt the functional organization of the human brain. Psychiatry Res (2008) 162:205-13. doi:10.1016/j.pscychresns.2007.04.010

51. Hartley T, Lever C, Burgess N, O'Keefe J. Space in the brain: how the hippocampal formation supports spatial cognition. Philos Trans R Soc Lond B Biol Sci (2014) 369:20120510. doi:10.1098/rstb.2012.0510

52. Frankland PW, Cestari V, Filipkowski RK, McDonald RJ, Silva AJ. The dorsal hippocampus is essential for context discrimination but not for contextual conditioning. Behav Neurosci (1998) 112:863-74. doi:10.1037/ 0735-7044.112.4.863

53. Rolls ET. The mechanisms for pattern completion and pattern separation in the hippocampus. Front Syst Neurosci (2013) 7:74. doi:10.3389/fnsys.2013.00074

54. Eichenbaum H. Time cells in the hippocampus: a new dimension for mapping memories. Nat Rev Neurosci (2014) 15:732-44. doi:10.1038/nrn3827

55. Aimone JB, Li Y, Lee SW, Clemenson GD, Deng W, Gage FH. Regulation and function of adult neurogenesis: from genes to cognition. Physiol Rev (2014) 94:991-1026. doi:10.1152/physrev.00004.2014

56. Clelland CD, Choi M, Romberg C, Clemenson GD Jr, Fragniere A, Tyers P, et al. A functional role for adult hippocampal neurogenesis in spatial pattern separation. Science (2009) 325:210-3. doi:10.1126/science.1173215

57. Rive MM, van Rooijen G, Veltman DJ, Phillips ML, Schene AH, Ruhe HG. Neural correlates of dysfunctional emotion regulation in major depressive disorder. A systematic review of neuroimaging studies. Neurosci Biobehav $\operatorname{Rev}(2013)$ 37:2529-53. doi:10.1016/j.neubiorev.2013.07.018

58. Koob GF, Volkow ND. Neurocircuitry of addiction. Neuropsychopharmacology (2010) 35:217-38. doi:10.1038/npp.2010.4

59. Peterson JB, Rothfleisch J, Zelazo PD, Pihl RO. Acute alcohol intoxication and cognitive functioning. J Stud Alcohol (1990) 51:114-22. doi:10.15288/ jsa.1990.51.114

60. Pfefferbaum A, Lim KO, Zipursky RB, Mathalon DH, Rosenbloom MJ, Lane B, et al. Brain gray and white matter volume loss accelerates with aging in chronic alcoholics: a quantitative MRI study. Alcohol Clin Exp Res (1992) 16:1078-89. doi:10.1111/j.1530-0277.1992.tb00702.x

61. Pfefferbaum A, Sullivan EV, Mathalon DH, Lim KO. Frontal lobe volume loss observed with magnetic resonance imaging in older chronic alcoholics. Alcohol Clin Exp Res (1997) 21:521-9. doi:10.1111/j.1530-0277.1997. tb03798.x

62. Schweinsburg BC, Taylor MJ, Alhassoon OM, Videen JS, Brown GG, Patterson TL, et al. Chemical pathology in brain white matter of recently detoxified alcoholics: a $1 \mathrm{H}$ magnetic resonance spectroscopy investigation of alcohol-associated frontal lobe injury. Alcohol Clin Exp Res (2001) 25:924-34. doi:10.1111/j.1530-0277.2001.tb02299.x

63. Rando K, Hong KI, Bhagwagar Z, Li CS, Bergquist K, Guarnaccia J, et al. Association of frontal and posterior cortical gray matter volume with time to alcohol relapse: a prospective study. Am J Psychiatry (2011) 168:183-92. doi:10.1176/appi.ajp.2010.10020233

64. Le Berre AP, Rauchs G, La Joie R, Mezenge F, Boudehent C, Vabret F, et al. Impaired decision-making and brain shrinkage in alcoholism. Eur Psychiatry (2014) 29:125-33. doi:10.1016/j.eurpsy.2012.10.002
65. Zorlu N, Gelal F, Kuserli A, Cenik E, Durmaz E, Saricicek A, et al. Abnormal white matter integrity and decision-making deficits in alcohol dependence. Psychiatry Res (2013) 214:382-8. doi:10.1016/j.pscychresns.2013. 06.014

66. Fortier CB, Leritz EC, Salat DH, Lindemer E, Maksimovskiy AL, Shepel J, et al. Widespread effects of alcohol on white matter microstructure. Alcohol Clin Exp Res (2014) 38:2925-33. doi:10.1111/acer.12568

67. Zorlu N, Karavul Ucman T, Gelal F, Colak Kalayci C, Polat S, Saricicek A, et al. Abnormal white matter integrity in long-term abstinent alcohol dependent patients. Psychiatry Res (2014) 224:42-8. doi:10.1016/ j.pscychresns.2014.07.006

68. Rogers BP, Parks MH, Nickel MK, Katwal SB, Martin PR. Reduced fronto-cerebellar functional connectivity in chronic alcoholic patients. Alcohol Clin Exp Res (2012) 36:294-301. doi:10.1111/j.1530-0277.2011. 01614.x

69. Dresler T, Schecklmann M, Ernst LH, Pohla C, Warrings B, Fischer M, et al. Recovery of cortical functioning in abstinent alcohol-dependent patients: prefrontal brain oxygenation during verbal fluency at different phases during withdrawal. World J Biol Psychiatry (2012) 13:135-45. doi:10.3109/1562297 5.2011 .564654

70. Seo D, Lacadie CM, Tuit K, Hong KI, Constable RT, Sinha R. Disrupted ventromedial prefrontal function, alcohol craving, and subsequent relapse risk. JAMA Psychiatry (2013) 70:727-39. doi:10.1001/jamapsychiatry. 2013.762

71. Kril JJ, Halliday GM, Svoboda MD, Cartwright H. The cerebral cortex is damaged in chronic alcoholics. Neuroscience (1997) 79:983-98. doi:10.1016/ S0306-4522(97)00083-3

72. Fitzhugh LC, Fitzhugh KB, Reitan RM. Adaptive abilities and intellectual functioning in hospitalized alcoholics. Q J Stud Alcohol (1960) 21:414-23.

73. Fitzhugh LC, Fitzhugh KB, Reitan RM. Adaptive abilities and intellectual functioning of hospitalized alcoholics: further considerations. Q J Stud Alcohol (1965) 26:402-11.

74. Green A, Garrick T, Sheedy D, Blake H, Shores EA, Harper C. The effect of moderate to heavy alcohol consumption on neuropsychological performance as measured by the repeatable battery for the assessment of neuropsychological status. Alcohol Clin Exp Res (2010) 34:443-50. doi:10.1111/j.1530-0277.2009.01108.x

75. Houston RJ, Derrick JL, Leonard KE, Testa M, Quigley BM, Kubiak A. Effects of heavy drinking on executive cognitive functioning in a community sample. Addict Behav (2014) 39:345-9. doi:10.1016/j.addbeh.2013.09.032

76. Finn PR, Mazas CA, Justus AN, Steinmetz J. Early-onset alcoholism with conduct disorder: go/no go learning deficits, working memory capacity, and personality. Alcohol Clin Exp Res (2002) 26:186-206. doi:10.111 1/j.1530-0277.2002.tb02524.x

77. Kopera M, Wojnar M, Brower K, Glass J, Nowosad I, Gmaj B, et al. Cognitive functions in abstinent alcohol-dependent patients. Alcohol (2012) 46:665-71. doi:10.1016/j.alcohol.2012.04.005

78. Petry NM. Delay discounting of money and alcohol in actively using alcoholics, currently abstinent alcoholics, and controls. Psychopharmacology (Berl) (2001) 154:243-50. doi:10.1007/s002130000638

79. Bjork JM, Hommer DW, Grant SJ, Danube C. Impulsivity in abstinent alcohol-dependent patients: relation to control subjects and type 1-/type 2-like traits. Alcohol (2004) 34:133-50. doi:10.1016/j.alcohol.2004.06.012

80. Li CS, Luo X, Yan P, Bergquist K, Sinha R. Altered impulse control in alcohol dependence: neural measures of stop signal performance. Alcohol Clin Exp Res (2009) 33:740-50. doi:10.1111/j.1530-0277.2008.00891.x

81. Lejuez CW, Magidson JF, Mitchell SH, Sinha R, Stevens MC, de Wit H. Behavioral and biological indicators of impulsivity in the development of alcohol use, problems, and disorders. Alcohol Clin Exp Res (2010) 34:1334-45. doi:10.1111/j.1530-0277.2010.01217.x

82. Pandey AK, Kamarajan C, Tang Y, Chorlian DB, Roopesh BN, Manz N, et al. Neurocognitive deficits in male alcoholics: an ERP/sLORETA analysis of the N2 component in an equal probability Go/NoGo task. Biol Psychol (2012) 89:170-82. doi:10.1016/j.biopsycho.2011.10.009

83. Nakamura-Palacios EM, Souza RS, Zago-Gomes MP, de Melo AM, Braga FS, Kubo TT, et al. Gray matter volume in left rostral middle frontal and left cerebellar cortices predicts frontal executive performance in alcoholic subjects. Alcohol Clin Exp Res (2014) 38:1126-33. doi:10.1111/acer.12308 
84. Chanraud S, Pitel AL, Muller-Oehring EM, Pfefferbaum A, Sullivan EV. Remapping the brain to compensate for impairment in recovering alcoholics. Cereb Cortex (2013) 23:97-104. doi:10.1093/cercor/bhr381

85. Kurth C, Wegerer V, Reulbach U, Lewczuk P, Kornhuber J, Steinhoff BJ, et al. Analysis of hippocampal atrophy in alcoholic patients by a Kohonen feature map.Neuroreport (2004) 15:367-71.doi:10.1097/00001756-200402090-00031

86. Oscar-Berman M, Song J. Brain volumetric measures in alcoholics: a comparison of two segmentation methods. Neuropsychiatr Dis Treat (2011) 7:65-75. doi:10.2147/NDT.S13405

87. Fein G, Fein D. Subcortical volumes are reduced in short-term and longterm abstinent alcoholics but not those with a comorbid stimulant disorder. Neuroimage Clin (2013) 3:47-53. doi:10.1016/j.nicl.2013.06.018

88. Bengochea O, Gonzalo LM. Effect of chronic alcoholism on the human hippocampus. Histol Histopathol (1990) 5:349-57.

89. Suzuki Y, Oishi M, Ogawa K, Mizutani T. Atrophy of the parahippocampal gyrus and regional cerebral blood flow in the limbic system in chronic alcoholic patients. Alcohol (2010) 44:439-45. doi:10.1016/j.alcohol.2010.05.003

90. Dager AD, Jamadar S, Stevens MC, Rosen R, Jiantonio-Kelly RE, Sisante JF, et al. fMRI response during figural memory task performance in college drinkers. Psychopharmacology (Berl) (2014) 231:167-79. doi:10.1007/ s00213-013-3219-1

91. Burgess N, Maguire EA, O'Keefe J. The human hippocampus and spatial and episodic memory. Neuron (2002) 35:625-41. doi:10.1016/ S0896-6273(02)00830-9

92. Nadel L, Ryan L, Hayes SM, Gilboa A, Moscovich M. The role of the hippocampal complex in long-term episodic memory. Int Congr Ser (2003) 1250:215-34. doi:10.1016/S0531-5131(03)01069-0

93. Pitel AL, Beaunieux H, Witkowski T, Vabret F, Guillery-Girard B, Quinette P, et al. Genuine episodic memory deficits and executive dysfunctions in alcoholic subjects early in abstinence. Alcohol Clin Exp Res (2007) 31: 1169-78. doi:10.1111/j.1530-0277.2007.00418.x

94. Pitel AL, Witkowski T, Vabret F, Guillery-Girard B, Desgranges B, Eustache F, et al. Effect of episodic and working memory impairments on semantic and cognitive procedural learning at alcohol treatment entry. Alcohol Clin Exp Res (2007) 31:238-48. doi:10.1111/j.1530-0277.2006. 00301.x

95. Pitel AL, Rivier J, Beaunieux H, Vabret F, Desgranges B, Eustache F. Changes in the episodic memory and executive functions of abstinent and relapsed alcoholics over a 6-month period. Alcohol Clin Exp Res (2009) 33:490-8. doi:10.1111/j.1530-0277.2008.00859.x

96. Noel X, Van der Linden M, Brevers D, Campanella S, Hanak C, Kornreich C, et al. The contribution of executive functions deficits to impaired episodic memory in individuals with alcoholism. Psychiatry Res (2012) 198:116-22. doi:10.1016/j.psychres.2011.10.007

97. Schacht JP, Randall PK, Waid LR, Baros AM, Latham PK, Wright TM, et al. Neurocognitive performance, alcohol withdrawal, and effects of a combination of flumazenil and gabapentin in alcohol dependence. Alcohol Clin Exp Res (2011) 35:2030-8. doi:10.1111/j.1530-0277.2011. 01554.x

98. Joyce EM, Robbins TW. Frontal lobe function in Korsakoff and non-Korsakoff alcoholics: planning and spatial working memory. Neuropsychologia (1991) 29:709-23. doi:10.1016/0028-3932(91)90067-I

99. Tivis R, Beatty WW, Nixon SJ, Parsons OA. Patterns of cognitive impairment among alcoholics: are there subtypes? Alcohol Clin Exp Res (1995) 19:496-500. doi:10.1111/j.1530-0277.1995.tb01537.x

100. Moselhy HF, Georgiou G, Kahn A. Frontal lobe changes in alcoholism: a review of the literature. Alcohol Alcohol (2001) 36:357-68. doi:10.1093/ alcalc/36.5.357

101. Brokate B, Hildebrandt H, Eling P, Fichtner H, Runge K, Timm C. Frontal lobe dysfunctions in Korsakoff's syndrome and chronic alcoholism: continuity or discontinuity? Neuropsychology (2003) 17:420-8. doi:10.1037/0894-4105.17.3.420

102. Stavro K, Pelletier J, Potvin S. Widespread and sustained cognitive deficits in alcoholism: a meta-analysis. Addict Biol (2013) 18:203-13. doi:10.1111/j.1369-1600.2011.00418.x

103. Loeber S, Duka T, Welzel Marquez H, Nakovics H, Heinz A, Mann K, et al. Effects of repeated withdrawal from alcohol on recovery of cognitive impairment under abstinence and rate of relapse. Alcohol Alcohol (2010) 45:541-7. doi:10.1093/alcalc/agq065
104. Oscar-Berman M, Valmas MM, Sawyer KS, Ruiz SM, Luhar RB, Gravitz ZR. Profiles of impaired, spared, and recovered neuropsychologic processes in alcoholism. Handb Clin Neurol (2014) 125:183-210. doi:10.1016/ B978-0-444-62619-6.00012-4

105. Glenn SW, Parsons OA. Neuropsychological efficiency measures in male and female alcoholics. JStud Alcohol (1992) 53:546-52. doi:10.15288/ jsa.1992.53.546

106. Munro CA, Saxton J, Butters MA. The neuropsychological consequences of abstinence among older alcoholics: a cross-sectional study. Alcohol Clin Exp Res (2000) 24:1510-6. doi:10.1111/j.1530-0277.2000.tb04569.x

107. D’Argembeau A, Van Der Linden M, Verbanck P, Noel X. Autobiographical memory in non-amnesic alcohol-dependent patients. Psychol Med (2006) 36:1707-15. doi:10.1017/S0033291706008798

108. Brandt J, Butters N, Ryan C, Bayog R. Cognitive loss and recovery in longterm alcohol abusers. Arch Gen Psychiatry (1983) 40:435-42. doi:10.1001/ archpsyc.1983.01790040089012

109. Vertes RP. Interactions among the medial prefrontal cortex, hippocampus and midline thalamus in emotional and cognitive processing in the rat. Neuroscience (2006) 142:1-20. doi:10.1016/j.neuroscience.2006.06.027

110. Planeta CS. Animal models of alcohol and drug dependence. Rev Bras Psiquiatr (2013) 35:S140-6. doi:10.1590/1516-4446-2013-1149

111. Kroener S, Mulholland PJ, New NN, Gass JT, Becker HC, Chandler LJ. Chronic alcohol exposure alters behavioral and synaptic plasticity of the rodent prefrontal cortex. PLoS One (2012) 7:e37541. doi:10.1371/journal. pone. 0037541

112. Holmes A, Fitzgerald PJ, MacPherson KP, DeBrouse L, Colacicco G, Flynn SM, et al. Chronic alcohol remodels prefrontal neurons and disrupts NMDAR-mediated fear extinction encoding. Nat Neurosci (2012) 15: 1359-61. doi:10.1038/nn.3204

113. Trantham-Davidson H, Burnett EJ, Gass JT, Lopez MF, Mulholland PJ, Centanni SW, et al. Chronic alcohol disrupts dopamine receptor activity and the cognitive function of the medial prefrontal cortex. J Neurosci (2014) 34:3706-18. doi:10.1523/JNEUROSCI.0623-13.2014

114. Dominguez G, Belzung C, Pierard C, David V, Henkous N, Decorte L, et al. Alcohol withdrawal induces long-lasting spatial working memory impairments: relationship with changes in corticosterone response in the prefrontal cortex. Addict Biol (2016). doi:10.1111/adb.12371

115. Dominguez G, Dagnas M, Decorte L, Vandesquille M, Belzung C, Beracochea D, et al. Rescuing prefrontal cAMP-CREB pathway reverses working memory deficits during withdrawal from prolonged alcohol exposure. Brain Struct Funct (2016) 221:865-77. doi:10.1007/s00429-0140941-3

116. Badanich KA, Becker HC, Woodward JJ. Effects of chronic intermittent ethanol exposure on orbitofrontal and medial prefrontal cortex-dependent behaviors in mice. Behav Neurosci (2011) 125:879-91. doi:10.1037/ a0025922

117. Beracochea D, Jaffard R. Memory deficits subsequent to chronic consumption of alcohol in mice: an analysis based on spontaneous alternation behavior. Behav Brain Res (1985) 15:15-25. doi:10.1016/0166-4328(85)90014-2

118. Beracochea D, Micheau J, Jaffard R. Memory deficits following chronic alcohol consumption in mice: relationships with hippocampal and cortical cholinergic activities. Pharmacol Biochem Behav (1992) 42:749-53. doi:10.1016/0091-3057(92)90024-A

119. Franke H, Kittner H, Berger P, Wirkner K, Schramek J. The reaction of astrocytes and neurons in the hippocampus of adult rats during chronic ethanol treatment and correlations to behavioral impairments. Alcohol (1997) 14:445-54. doi:10.1016/S0741-8329(96)00209-1

120. Lukoyanov NV, Madeira MD, Paula-Barbosa MM. Behavioral and neuroanatomical consequences of chronic ethanol intake and withdrawal. Physiol Behav (1999) 66:337-46. doi:10.1016/S0031-9384(98)00301-1

121. Cagetti E, Pinna G, Guidotti A, Baicy K, Olsen RW. Chronic intermittent ethanol (CIE) administration in rats decreases levels of neurosteroids in hippocampus, accompanied by altered behavioral responses to neurosteroids and memory function. Neuropharmacology (2004) 46:570-9. doi:10.1016/ j.neuropharm.2003.10.001

122. Hashemi Nosrat Abadi T, Vaghef L, Babri S, Mahmood-Alilo M, Beirami M. Effects of different exercise protocols on ethanol-induced spatial memory impairment in adult male rats. Alcohol (2013) 47:309-16. doi:10.1016/ j.alcohol.2013.01.008 
123. Morris RG. NMDA receptors and memory encoding. Neuropharmacology (2013) 74:32-40. doi:10.1016/j.neuropharm.2013.04.014

124. Masood K, Wu C, Brauneis U, Weight FF. Differential ethanol sensitivity of recombinant N-methyl-D-aspartate receptor subunits. Mol Pharmacol (1994) 45:324-9.

125. Chu B, Anantharam V, Treistman SN. Ethanol inhibition of recombinant heteromeric NMDA channels in the presence and absence of modulators. J Neurochem (1995) 65:140-8. doi:10.1046/j.1471-4159.1995. 65010140.x

126. Mirshahi T, Woodward JJ. Ethanol sensitivity of heteromeric NMDA receptors: effects of subunit assembly, glycine and NMDAR1 $\mathrm{Mg}(2+)$ insensitive mutants. Neuropharmacology (1995) 34:347-55. doi:10.1016/ 0028-3908(94)00155-L

127. Allgaier C. Ethanol sensitivity of NMDA receptors. Neurochem Int (2002) 41:377-82. doi:10.1016/S0197-0186(02)00046-3

128. Wright JM, Peoples RW, Weight FF. Single-channel and whole-cell analysis of ethanol inhibition of NMDA-activated currents in cultured mouse cortical and hippocampal neurons. Brain Res (1996) 738:249-56. doi:10.1016/ S0006-8993(96)00780-9

129. Mohler $\mathrm{H}$. Molecular regulation of cognitive functions and developmental plasticity: impact of GABAA receptors. J Neurochem (2007) 102:1-12. doi:10.1111/j.1471-4159.2007.04454.x

130. Mehta AK, Ticku MK. Ethanol potentiation of GABAergic transmission in cultured spinal cord neurons involves gamma-aminobutyric acidA-gated chloride channels. J Pharmacol Exp Ther (1988) 246:558-64.

131. Sundstrom-Poromaa I, Smith DH, Gong QH, Sabado TN, Li X, Light A, et al. Hormonally regulated alpha(4)beta(2)delta GABA(A) receptors are a target for alcohol. Nat Neurosci (2002) 5:721-2. doi:10.1038/nn888

132. Sanchis-Segura C, Cline B, Jurd R, Rudolph U, Spanagel R. Etomidate and propofol-hyposensitive GABAA receptor beta3(N265M) mice show little changes in acute alcohol sensitivity but enhanced tolerance and withdrawal. Neurosci Lett (2007) 416:275-8. doi:10.1016/j.neulet.2007. 02.024

133. Salter MW, Kalia LV. Src kinases: a hub for NMDA receptor regulation. Nat Rev Neurosci (2004) 5:317-28. doi:10.1038/nrn1368

134. Kalluri HS, Mehta AK, Ticku MK. Up-regulation of NMDA receptor subunits in rat brain following chronic ethanol treatment. Brain Res Mol Brain Res (1998) 58:221-4. doi:10.1016/S0169-328X(98)00112-0

135. Henniger MS, Wotjak CT, Holter SM. Long-term voluntary ethanol drinking increases expression of NMDA receptor $2 \mathrm{~B}$ subunits in rat frontal cortex. Eur J Pharmacol (2003) 470:33-6. doi:10.1016/S0014-2999(03)01787-4

136. Carpenter-Hyland EP, Woodward JJ, Chandler LJ. Chronic ethanol induces synaptic but not extrasynaptic targeting of NMDA receptors. JNeurosci (2004) 24:7859-68. doi:10.1523/JNEUROSCI.1902-04.2004

137. Staples MC, Kim A, Mandyam CD. Dendritic remodeling of hippocampal neurons is associated with altered NMDA receptor expression in alcohol dependent rats. Mol Cell Neurosci (2015) 65:153-62. doi:10.1016/ j.mcn.2015.03.008

138. Kumar S, Porcu P, Werner DF, Matthews DB, Diaz-Granados JL, Helfand RS, et al. The role of $\operatorname{GABA}(\mathrm{A})$ receptors in the acute and chronic effects of ethanol: a decade of progress. Psychopharmacology (Berl) (2009) 205:529-64. doi:10.1007/s00213-009-1562-z

139. Charlton ME, Sweetnam PM, Fitzgerald LW, Terwilliger RZ, Nestler EJ, Duman RS. Chronic ethanol administration regulates the expression of GABAA receptor alpha 1 and alpha 5 subunits in the ventral tegmental area and hippocampus. J Neurochem (1997) 68:121-7. doi:10.1046/j.14714159.1997.68010121.x

140. Mahmoudi M, Kang MH, Tillakaratne N, Tobin AJ, Olsen RW. Chronic intermittent ethanol treatment in rats increases GABA(A) receptor alpha4-subunit expression: possible relevance to alcohol dependence. J Neurochem (1997) 68:2485-92. doi:10.1046/j.1471-4159.1997.68062485.x

141. Matthews DB, Devaud LL, Fritschy JM, Sieghart W, Morrow AL. Differential regulation of $\mathrm{GABA}(\mathrm{A})$ receptor gene expression by ethanol in the rat hippocampus versus cerebral cortex. JNeurochem (1998) 70:1160-6. doi:10.1046/j.1471-4159.1998.70031160.x

142. Cagetti E, Liang J, Spigelman I, Olsen RW. Withdrawal from chronic intermittent ethanol treatment changes subunit composition, reduces synaptic function, and decreases behavioral responses to positive allosteric modulators of GABAA receptors. Mol Pharmacol (2003) 63:53-64. doi:10.1124/ mol.63.1.53

143. Liang J, Cagetti E, Olsen RW, Spigelman I. Altered pharmacology of synaptic and extrasynaptic GABAA receptors on CA1 hippocampal neurons is consistent with subunit changes in a model of alcohol withdrawal and dependence. J Pharmacol Exp Ther (2004) 310:1234-45. doi:10.1124/jpet. 104.067983

144. Liang J, Zhang N, Cagetti E, Houser CR, Olsen RW, Spigelman I. Chronic intermittent ethanol-induced switch of ethanol actions from extrasynaptic to synaptic hippocampal GABAA receptors. J Neurosci (2006) 26:1749-58. doi:10.1523/JNEUROSCI.4702-05.2006

145. Kumar S, Kralic JE, O’Buckley TK, Grobin AC, Morrow AL. Chronic ethanol consumption enhances internalization of alphal subunit-containing GABAA receptors in cerebral cortex. JNeurochem (2003) 86:700-8. doi:10.1046/j.1471-4159.2003.01894.x

146. BonfantiL,PerettoP.Adultneurogenesisinmammals-athemewithmanyvariations. EurJ Neurosci (2011) 34:930-50. doi:10.1111/j.1460-9568.2011.07832.x

147. Drew LJ, Fusi S, Hen R. Adult neurogenesis in the mammalian hippocampus: why the dentate gyrus? Learn Mem (2013) 20:710-29. doi:10.1101/ $\operatorname{lm} .026542 .112$

148. Koob GF. Addiction is a reward deficit and stress surfeit disorder. Front Psychiatry (2013) 4:72. doi:10.3389/fpsyt.2013.00072

149. Mandyam CD. The interplay between the hippocampus and amygdala in regulating aberrant hippocampal neurogenesis during protracted abstinence from alcohol dependence. Front Psychiatry (2013) 4:61. doi:10.3389/ fpsyt.2013.00061

150. Kaplan MS, Hinds JW. Neurogenesis in the adult rat: electron microscopic analysis of light radioautographs. Science (1977) 197:1092-4. doi:10.1126/ science. 887941

151. Abrous DN, Koehl M, Le Moal M. Adult neurogenesis: from precursors to network and physiology. Physiol Rev (2005) 85:523-69. doi:10.1152/ physrev.00055.2003

152. Eriksson PS, Perfilieva E, Bjork-Eriksson T, Alborn AM, Nordborg C, Peterson DA, et al. Neurogenesis in the adult human hippocampus. Nat Med (1998) 4:1313-7. doi:10.1038/3305

153. Kempermann G, Jessberger S, Steiner B, Kronenberg G. Milestones of neuronal development in the adult hippocampus. Trends Neurosci (2004) 27:447-52. doi:10.1016/j.tins.2004.05.013

154. Epp JR, Chow C, Galea LA. Hippocampus-dependent learning influences hippocampal neurogenesis. Front Neurosci (2013) 7:57. doi:10.3389/ fnins.2013.00057

155. Marin-Burgin A, Schinder AF. Requirement of adult-born neurons for hippocampus-dependent learning. Behav Brain Res (2012) 227:391-9. doi:10.1016/j.bbr.2011.07.001

156. Shors TJ, Townsend DA, Zhao M, Kozorovitskiy Y, Gould E. Neurogenesis may relate to some but not all types of hippocampal-dependent learning. Hippocampus (2002) 12:578-84. doi:10.1002/hipo.10103

157. Raybuck JD, Lattal KM. Bridging the interval: theory and neurobiology of trace conditioning. Behav Processes (2014) 101c:103-11. doi:10.1016/j. beproc.2013.08.016

158. Nacher J, Varea E, Miguel Blasco-Ibanez J, Gomez-Climent MA, CastilloGomez E, Crespo C, et al. N-methyl-D-aspartate receptor expression during adult neurogenesis in the rat dentate gyrus. Neuroscience (2007) 144:855-64. doi:10.1016/j.neuroscience.2006.10.021

159. Bruel-Jungerman E, Davis S, Rampon C, Laroche S. Long-term potentiation enhances neurogenesis in the adult dentate gyrus. J Neurosci (2006) 26:5888-93. doi:10.1523/JNEUROSCI.0782-06.2006

160. Chun SK, Sun W, Park JJ, Jung MW. Enhanced proliferation of progenitor cells following long-term potentiation induction in the rat dentate gyrus. Neurobiol Learn Mem (2006) 86:322-9. doi:10.1016/j.nlm.2006.05.005

161. Pallotto M, Deprez F. Regulation of adult neurogenesis by GABAergic transmission: signaling beyond GABAA-receptors. Front Cell Neurosci (2014) 8:166. doi:10.3389/fncel.2014.00166

162. Wei W, Zhang N, Peng Z, Houser CR, Mody I. Perisynaptic localization of delta subunit-containing GABA(A) receptors and their activation by GABA spillover in the mouse dentate gyrus. J Neurosci (2003) 23:10650-61. 
163. Heldt SA, Ressler KJ. Forebrain and midbrain distribution of major benzodiazepine-sensitive GABAA receptor subunits in the adult C57 mouse as assessed with in situ hybridization. Neuroscience (2007) 150:370-85. doi:10.1016/j.neuroscience.2007.09.008

164. Hortnagl H, Tasan RO, Wieselthaler A, Kirchmair E, Sieghart W, Sperk G. Patterns of mRNA and protein expression for 12 GABAA receptor subunits in the mouse brain. Neuroscience (2013) 236:345-72. doi:10.1016/ j.neuroscience.2013.01.008

165. Song J, Christian K, Ming GL, Song H. Modification of hippocampal circuitry by adult neurogenesis. Dev Neurobiol (2012) 72(7):1032-43. doi:10.1002/ dneu. 22014

166. Moss J, Toni N. A circuit-based gatekeeper for adult neural stem cell proliferation: parvalbumin-expressing interneurons of the dentate gyrus control the activation and proliferation of quiescent adult neural stem cells. Bioessays (2013) 35:28-33. doi:10.1002/bies.201200136

167. Nixon K, Crews FT. Binge ethanol exposure decreases neurogenesis in adult rat hippocampus. J Neurochem (2002) 83:1087-93. doi:10.1046/ j.1471-4159.2002.01214.x

168. Richardson HN, Chan SH, Crawford EF, Lee YK, Funk CK, Koob GF, et al. Permanent impairment of birth and survival of cortical and hippocampal proliferating cells following excessive drinking during alcohol dependence. Neurobiol Dis (2009) 36:1-10. doi:10.1016/j.nbd.2009.05.021

169. Hansson AC, Nixon K, Rimondini R, Damadzic R, Sommer WH, Eskay R, et al. Long-term suppression of forebrain neurogenesis and loss of neuronal progenitor cells following prolonged alcohol dependence in rats. Int J Neuropsychopharmacol (2010) 13:583-93. doi:10.1017/S1461145710000246

170. Nixon K, Crews FT. Temporally specific burst in cell proliferation increases hippocampal neurogenesis in protracted abstinence from alcohol. J Neurosci (2004) 24:9714-22. doi:10.1523/JNEUROSCI.3063-04.2004
171. Somkuwar SS, Fannon MJ, Staples MC, Zamora-Martinez ER, Navarro AI, $\mathrm{Kim} \mathrm{A}$, et al. Alcohol dependence-induced regulation of the proliferation and survival of adult brain progenitors is associated with altered BDNF-TrkB signaling. Brain Struct Funct (2015). doi:10.1007/s00429-015-1163-Z

172. Duveau V, Laustela S, Barth L, Gianolini F, Vogt KE, Keist R, et al. Spatiotemporal specificity of GABAA receptor-mediated regulation of adult hippocampal neurogenesis. Eur J Neurosci (2011) 34:362-73. doi:10.1111/ j.1460-9568.2011.07782.x

173. Nixon K. Alcohol and adult neurogenesis: roles in neurodegeneration and recovery in chronic alcoholism. Hippocampus (2006) 16:287-95. doi:10.1002/ hipo. 20162

174. Nixon K, Morris SA, Liput DJ, Kelso ML. Roles of neural stem cells and adult neurogenesis in adolescent alcohol use disorders. Alcohol (2010) 44:39-56. doi:10.1016/j.alcohol.2009.11.001

175. Kiefer F, Dinter C. New approaches to addiction treatment based on learning and memory. Curr Top Behav Neurosci (2013) 13:671-84. doi:10.1007/7854_2011_147

Conflict of Interest Statement: The authors declare that the research was conducted in the absence of any commercial or financial relationships that could be construed as a potential conflict of interest.

Copyright (c) 2016 Staples and Mandyam. This is an open-access article distributed under the terms of the Creative Commons Attribution License (CC BY). The use, distribution or reproduction in other forums is permitted, provided the original author(s) or licensor are credited and that the original publication in this journal is cited, in accordance with accepted academic practice. No use, distribution or reproduction is permitted which does not comply with these terms. 